\title{
SISTEM PENDUKUNG KEPUTUSAN DALAM MENENTUKAN HAKIM TERBAIK PADA PENGADILAN AGAMA KELAS 1A MEDAN MENERAPKAN METODE ANALYTICAL HIERARCY PROCESS (AHP) DAN PROMETHEE II
}

\author{
Dini Nofrisa ${ }^{1}, B_{\text {Berto }}$ Nadeak $^{2}$, Imam Saputra ${ }^{3}$
}

\author{
Program Studi Teknologi Informatika STMIK Budi Darma, Medan, Indonesia
}

\begin{abstract}
Abstrak
Kantor Pengadilan Agama Medan Kelas 1 A yang terletak di Jalan Sisingamangaraja KM 8.8 sebagai tempat yang menyelenggarakan penegakan hukum dan keadilan di tingkat pertama bagi rakyat pencari keadilan perkara tertentu antara orangorang yang beragama Islam di bidang perkawinan, waris, wasiat, hibah, wakaf, zakat, infaq, shadaqah dan ekonomi syariah. Di Kantor Pengadilan Agama Kelas 1A Medan terdapat beberapa jabatan yang di pimpin, dan terdapat beberapa hakim yang bertugas untuk memberikan keadilan untuk menyelesaikan perkara yang ditangani. Pihak Kantor Pengadilan Agama Medan Kelas 1 A memberikan sebuah reward atau penghargaan dengan tujuan meningkatkan kinerja Hakim yang bertugas, dan untuk menentukan Hakim terbaik maka dibutuhkan alternatif dan kriteria yang akan menjadi suatu acuan didalam proses pemilihan. Sistem Pendukung Keputusan merupakan salah satu cara yang bisa digunakan dalam proses pemilihan Hakim terbaik. Dalam penelitian ini, penulis menggunakan metode Analitycal Hierarchy Process (AHP) untuk mencari nilai bobot dari kriteria, dan metode Promethee II untuk mencari nilai akhir ataupun untuk mencari nilai perankingan Hakim terbaik. Dengan demikian Sistem Pendukung Keputusan sangat dibutuhkan agar dapat membantu pihak Kantor Pengadilan Agama Medan untuk menentukan Hakim terbaik.
\end{abstract}

Kata Kunci : Sistem Pendukung Keputusan, AHP, Promethee II, Pemilihan Hakim Terbaik

\begin{abstract}
Medan Religious Court Office Class 1 A located on Jalan Sisingamangaraja KM 8.8 as a place that organizes law enforcement and justice at the first level for people seeking justice for certain cases among people who are Muslim in the fields of marriage, inheritance, will, grant, endowment, zakat, infaq, shadaqah and sharia economics. In the Medan Class 1A Religious Courts Office there are a number of positions that are chaired, and there are several judges who are tasked with providing justice to settle cases handled. Medan Class 1 A Religious Court Office provides a reward or award with the aim of improving the performance of Judges on duty, and to determine the best Judges, alternatives and criteria are needed to be a reference in the selection process. Decision Support System is one method that can be used in the process of selecting the best Judges. In this study, the authors used the Analyticalcal Hierarchy Process (AHP) method to find the weighting value of the criteria, and the Promethee II method to find the final grade or to find the best Judge's ranking. Thus the Decision Support System is needed in order to help the Medan Religious Court Office to determine the best Judge.
\end{abstract}

Keywords: Decision Support System, AHP, Promethee II, Selection of the Best Judges

\section{PENDAhuluaN}

Kantor Pengadilan Agama Kelas 1A Medan adalah sebuah tempat yang menyelenggarakan penegakan hukum dan keadilan di tingkat pertama bagi rakyat pencari keadilan perkara tertentu antara orang-orang yang beragama Islam di bidang perkawinan, waris, wasiat, hibah, wakaf, zakat, infaq, shadaqah dan ekonomi syariah. Di Kantor Pengadilan Agama Kelas 1A Medan terdapat beberapa jabatan yang di pimpin, dan terdapat beberapa hakim yang bertugas untuk memberikan keadilan untuk menyelesaikan perkara yang ditangani.

Pada saat ini Kantor Pengadilan Agama Kelas 1 A Medan, selalu memberikan penghargaan kepada seluruh Hakim yang bertugas dengan tujuan untuk lebih meningkatkan kinerja Hakim agar lebih baik dan lebih bertanggung jawab terhadap tugas-tugas yang telah diberikan. Dalam menentukan Hakim yang terbaik maka dibutuhkan kriteriakriteria untuk setiap alternatif yang akan dipilih. Kantor Pengadilan Agama Medan Kelas 1A sudah melakukan pemilihan Hakim terbaik, tetapi masih kurang transparannya informasi mengenai proses pemilihan Hakim,sehingga proses pemilihan Hakim di Kantor Pengadilan Agama Medan Kelas 1 A masih kurang baik. Salah satu solusi untuk memilih Hakim terbaik adalah dengan membuat sistem pendukung keputusan. Sistem informasi yang dapat mendukung pengambilan suatu keputusan dikenal dengan nama Sistem Pendukung Keputusan (SPK), yang mampu memberikan kemampuan pemecahan masalah maupun kemampuan pengkomunikasian untuk masalah yang terstruktur maupun tidak terstruktur[1]. Sistem Pendukung Keputusan (SPK) ini bertujuan untuk menyediakan informasi, membimbing, memberikan solusi untuk melakukan pengambilan keputusan dengan lebih baik. Dengan adanya Sistem Pendukung Keputusan (SPK), maka akan mempermudah didalam menentukan suatu keputusan dengan hasil yang terbaik.

Di dalam Sistem Pendukung Keputusan (SPK) untuk menentukan pembobotan dapat digunakan metode PSI, AHP, TOPSIS dan didalam Sistem Pendukung Keputusan (SPK) untuk melakukan perangkingan dapat digunakan metode Promethee II, Exprom II, SAW . Metode Analytical Hierarchy Process (AHP) adalah metode.yang digunakan untuk mencari bobot. 
Analytical Hierarchy Process (AHP) merupakan sebuah metode yang digunakan untuk mencari pembobotan terhadap sistem pendukung keputusan. Kelebihan dari metode Analytical Hierarchy Process (AHP) adalah dapat menyelesaikan permasalahan yang kompleks, strukturnya tidak beraturan dan permasalahan yang tidak berstruktur sama sekali, sesuai dengan kemampuan dasar manusia dalam memberikan penilaian[2]. Metode Promethee II digunakan dalam mencari perangkingan, metode ini digunakan untuk mencari hasil akhir dengan cara membandingkan satu alternatif dengan alternatif yang lainnya, yang mendapatkan nilai tertinggi maka itulah yang terbaik sehingga mempermudah di dalam menentukan perangkingan[3]. Didalam melakukan penelitian maka penulis menggunakan metode Analytical Hierarchy Process (AHP) untuk menentukan pembobotan, dan menggunakan metode Promethee II dalam melakukan perangkingan untuk memilih Hakim terbaik.

\section{TEORITIS}

\section{Sistem Pendukung Keputusan}

Sistem informasi yang dapat mendukung pengambilan suatu keputusan dikenal dengan nama Sistem Pendukung Keputusan (SPK), yang mampu memberikan kemampuan pemecahan masalah maupun kemampuan pengkomunikasian untuk masalah yang terstruktur maupun tidak terstruktur[1].

\section{Hakim}

Hakim merupakan salah satu unsur utama disebuah pengadilan yang memiliki peran untuk mengadili sebuah perkara. Hakim adalah pejabat yang melaksanakan tugas kekuasaan kehakiman yang diartikan juga sebagai jabatan yang melaksanakan peraturan perundang-undangan yang memiliki posisi sangat penting disebuah Kantor Pengadilan maupun Mahkamah[5]. Hasil dari keputusan seorang Hakim tidak dapat diganggu gugat dan merupakan hasil akhir di dalam sebuah perkara. Seorang Hakim harus memiliki moralitas yang tinggi, harus memiliki sifat jujur dan juga adil didalam menjalankan tugasnya sebagai penegak keadilan.

\section{Analitycal Hierarchy Process (AHP)}

Analitycal Hierarchy Process (AHP) dikembangkan oleh Thomas L. Saaty pada tahun 1970-an. Metode ini merupakan salah satu model pengambilan keputusan multi kriteria yang dapat membantu kerangka berfikir manusia dalam menguraikan masalah menjadi suatu hirarki. Hirarki didefinisikan sebagai suatu representasi dari sebuah permasalahan yang kompleks dalam suatu struktur multi level dimana level pertama adalah tujuan, yang diikuti level faktor, kriteria, sub kriteria dan seterusnya ke bawah hingga level terakhir dari alternatif[6].

Adapun prinsip dasar metode Analitycal Hierarchy Process (AHP)[4] adalah sebagai berikut:

1. Membuat Hirarki

Sistem yang kompleks bisa dipahami dengan memecahnya menjadi elemen- elemen pendukung.

2. Penilaian kriteria dan alternatif

Kriteria dan hirarki dilakukakan dengan perbandingan berpasangan, untuk berbagai persoalan, skala 1 sampai 9 adalah skala terbaik untuk mengekspresikan pendapat. Nilai dan skala definisi kualitatif dari skala perbandingan bisa diukur menggunakan tabel analisis seperti yang ada pada tabel 3.1 di bawah ini.

Tabel 1.Skala Penilaian Perbandingan Pasangan

\begin{tabular}{cl}
\hline $\begin{array}{c}\text { Intensitas } \\
\text { Kepentingan }\end{array}$ & \multicolumn{1}{c}{ Keterangan } \\
\hline 1 & Kedua elemen sama pentingnya \\
3 & Elemen yang satu sedikit lebih penting daripada elemen yang lainnya \\
5 & Elemen yang satu lebih penting daripada elemen lainnya \\
7 & Satu elemen jelas lebih mutlak penting daripada elemen lainnya \\
9 & Satu elemen mutlak penting daripada elemen lainnya \\
$2,4,6,8$ & Nilai-nilai antara dua nilai pertimbangan yang berdekatan \\
Kebalikan & Jika aktivitas i mendapat satu angka dibandingkan dengan aktivitas j, maka i memiliki nilai \\
& kebalikannya dibandingkan nilai j \\
\hline
\end{tabular}

3. Menentukan nilai keseluruhan prioritas atau Total Priority Value (TPV) dengan menjumlahkan nilai tiap kolom dan membagi dengan jumlah kolom.

4. Memeriksa konsistensi Consistency Ratio (CR) dengan langkah-langkah sebagai berikut:

a. Menentukan nilai rata-rata ( $\lambda$ maks) dengan rumus :

$\lambda$ maks $=(\lambda$ maks K $1++\lambda$ maks Kn $) / \mathrm{n}$

Keterangan : $\lambda$ maks $=$ Nilai Rata - Rata Kriteria

$\mathrm{K} \quad=$ Kriteria

$\mathrm{n}=$ Jumlah Kriteria

b. Mencari nilai Consistency Index (CI) dengan rumus : 
$\mathrm{CI}=(\lambda$ maks-n/(n-1) $)$

Keterangan : $\mathrm{CI}=$ Consistency Index

$\lambda$ maks $=$ Nilai Rata-Rata Kriteria

$\mathrm{n}=$ Jumlah Kriteria

c. Menghitung nilai Consistency Ratio (CR) dengan rumus :

$\mathrm{CR}=\mathrm{CI} / \mathrm{RI}$

Keterangan: $\mathrm{CR}=$ Consistency Ratio

$$
\begin{array}{ll}
\mathrm{CI} & =\text { Consistency Index } \\
\mathrm{RI} & =\text { Random Index. }
\end{array}
$$

\section{Promethee II}

Metode Promethee II adalah adalah sebuah metode untuk untuk menyelesaikan masalah pengambilan keputusan termasuk kedalam kategori MADM (Multi Attribute Decission Making). Promethee II sendiri merupakan metode baru yang menggunakan prinsip out rangking dan tujuan dari metode promethee yaitu untuk mempermudah proses pengambilan keputusan dengan cara mengelompokkan tipe keputusan yang dapat mewakili semua jenis keputusan.

Berikut langkah-langkah penyelesaian masalah dengan Metode Promethee II[3] sebagai berikut :

1. Menormalisasikan matriks keputusan dengan menggunakan persamaan sebagai berikut :

$R i j=[X i j-\min (X i j)] /[\max \quad(X i j-\min 0(X i j)]$

Untuk mencari kriteria cost dapat dituliskan ulang sebagai berikut ini;

$R i j=[\max (X i j)-X i j] /[\max \omega:(X i j-\min \%:(X i j)]$

$$
\begin{array}{lll}
\text { Keterangan : } & \text { Rij } & =\text { Matriks ternormalisasi } \\
& X i j \min & =\text { Nilai minimum } x i j \\
& \text { Xij max } & =\text { Nilai maksimum } x i j
\end{array}
$$

2. Menghitung fungsi preferensi $\mathrm{Pj}(\mathrm{i}, \mathrm{i})$

fungsi preferensi ini memerlukan definisi beberapa parameter preferensial, seperti preferensi dan batasan ketidak pedulian. Namun, dalam aplikasi real time, mungkin sulit bagi pengambil keputusan untuk menentukan fungsi preferensi spesifik yang sesuai untuk setiap kriteria dan juga untuk menentukan parameter yang terlibat. Adapun rumus yang digunakan yaitu;

$\left(\mathrm{i}, \mathrm{i}^{\prime}\right)=0$ jika $R i j \leq R i^{\prime} j$

$P j\left(\mathrm{i}, \mathrm{i}^{\prime}\right)=\left(R i j-R i^{\prime} j\right)$

Keterangan : i,i' = Alternatif yang akan dipasangkan

$\operatorname{Pj}\left(\mathrm{i}, \mathrm{i}^{\prime}\right)=$ Alternatif yang akan dipasangkan

3. Menghitung fungsi preferensi agregat dengan mempertimbangkan bobot kriteria.

Fungsi preferensi agregat

$\left(\mathrm{i}, \mathrm{i}^{\prime}\right)=\left[\Sigma W j m j=1 . P j\left(i, i^{\prime}\right)\right] / \Sigma W j m j=1$

Keterangan : i,i $\quad=$ Alternatif yang akan dipasangkan

$$
\begin{array}{ll}
\mathrm{WP} & =\text { Weak Preference } \\
\mathrm{mj} & =\text { Jumlah kriteria } \\
W_{j} & =\text { Bobot kriteria } j
\end{array}
$$

4. Tentukan arus keluar dan arus outranking sebagai berikut:

Mencari arus leaving flow:

(i) $=1 n-1\left[\Sigma \pi n i^{\prime}=1\left(i, i^{\prime}\right)\right] /(\mathrm{i} \neq i)$

Mencari arus entring flow:

(i) $=1 n-1\left[\Sigma \pi n i^{\prime}=1\left(i, i^{\prime}\right)\right] /(\mathrm{i} \neq i)$

Keterangan: $i \quad=$ alternatif

$$
\begin{array}{ll}
i & =\text { alternatif yang dipasangkan } \\
\mathrm{m} & =\text { jumlah alternatif } \\
\mathrm{n} & =\text { jumlah kriteria }
\end{array}
$$

5. Hitung arus outranking bersih untuk setiap alternatif

$$
\begin{array}{ll}
(i)=\varphi+(\mathrm{i})-\varphi-(\mathrm{i}) & \\
\text { Keterangan : } \varphi+ & =\text { Nilai leaving flow } \\
& \varphi^{-} \quad=\text { Nilai entering flow }
\end{array}
$$

\section{ANALISA DAN PEMBAHASAN}

Dalam proses pemilihan Hakim terbaik harus memenuhi krieria-kriteria yang telah ditetapkan di Kantor Pengadilan Agama Medan Kelas 1A. Proses pemilihan Hakim terbaik memiliki tujuan untuk meningkatkan kinerja Hakim dalam menjalanka tugasnya. 


\subsection{Kriteria Dan Bobot}

Kriteria yang digunakan untuk mencari Hakim terbaik menggunakan 5 kriteria yaitu, Masa Kerja, Pendidikan, Kedisiplinan, Loyalitas dan Prestasi. Kemudian kriteria-kriteria dibandingkan satu sama lain untuk mendapatkan nilai bobot. Untuk mendapatkan nilai bobot menggunakan metode Anaitical Hierarchy Process (AHP). Nilai-nilai tiap perbandingan tersebut didapat dari tabel penilaian perbandingan, dengan membandingkan kriteria yang satu dengan lai. Di bawah ini merupakan tabel perbandingan tiap kriteria.

Tabel 2 Nilai Perbandingan Kriteria

\begin{tabular}{|c|c|c|c|c|c|}
\hline Kriteria & Masa Kerja & Pendidikan & Kedisiplinan & Loyalitas & Prestasi \\
\hline Masa Kerja & 1 & 3 & 1 & 1 & 3 \\
\hline Pendidikan & 0.33 & 1 & 3 & 3 & 1 \\
\hline Kedisiplinan & 1 & 0.33 & 1 & 3 & 1 \\
\hline Loyalitas & 1 & 0.33 & 0.33 & 1 & 1 \\
\hline Prestasi & 0.33 & 1 & 1 & 1 & 1 \\
\hline Jumlah & 3.66 & 5.66 & 6.33 & 9 & 7 \\
\hline
\end{tabular}

Matriks keputusan yang ternormalisasi di buat dari hasil penjumlahan kolom diatas.

$$
\left[\begin{array}{ccccc}
1 & 3 & 1 & 1 & 3 \\
0.33 & 1 & 3 & 3 & 1 \\
1 & 0.33 & 1 & 3 & 1 \\
1 & 0.33 & 0.33 & 1 & 1 \\
0.33 & 1 & 1 & 1 & 1
\end{array}\right]
$$

a. Membuat matriks nilai kriteria

Matriks ini diperoleh dengan membagikan jumlah baris kolom 4 dengan jumlah masing-masing kolom yang ada di tabel 3

Tabel 3 Matriks Nilai Kriteria

\begin{tabular}{cccccc}
\hline Kriteria & Masa & Pendidikan & Kedisiplinan & Loyalitas & Prestasi \\
& Kerja & & & & \\
\hline Masa Kerja & 0.27 & 0.53 & 0.15 & 0.42 & 1.48 \\
Pendidikan & 0.09 & 0.17 & 0.47 & 0.14 & 1.2 \\
Kedisiplinan & 0.27 & 0.05 & 0.15 & 0.14 & 0.94 \\
Loyalitas & 0.27 & 0.05 & 0.05 & 0.14 & 0.62 \\
Prestasi & 0.09 & 0.17 & 0.15 & 0.14 & 0.66 \\
\hline
\end{tabular}

Matriks keputusan yang ternormalisasi di buat dari hasil pembagian baris kolom dengan jumlah masing-masing kolom diatas.

$\left[\begin{array}{lllll}0.27 & 0.53 & 0.15 & 0.11 & 0.42 \\ 0.09 & 0.17 & 0.47 & 0.33 & 0.14 \\ 0.27 & 0.05 & 0.15 & 0.33 & 0.14 \\ 0.27 & 0.05 & 0.05 & 0.11 & 0.14 \\ 0.09 & 0.17 & 0.15 & 0.11 & 0.14\end{array}\right]$

Setelah matriks normalisasi didapatkan, langkah selanjutnya adalah menjumlahkan tiap baris pada matriks tersebut.Menghitung nilai Consistency Ratio (CR) dengan langkah-langkah sebagai berikut:

$$
\begin{aligned}
& \text { Masa Kerja } \quad: 0.27+0.53+0.15+0.11+0.42=1.48 \\
& \text { Pendidikan } \quad: 0.09+0.17+0.47+0.33+0.14=1.2 \\
& \text { Kedisiplinan } \quad: 0.27+0.05+0.15+0.33+0.14=0.94 \\
& \text { Loyalitas : } 0.27+0.05+0.05+0.11+0.14=0,62 \\
& \text { Prestasi Kerja } \quad: 0.09+0.17+0.15+0.11+0.14=0.66
\end{aligned}
$$

Setelah didapatkan jumlah pada masing-masing baris, kemudian dihitung nilai prioritas kriteria dengan cara membagi masing-masing jumlah kriteria $(n=5)$, sehingga nilai prioritas masing-masing kriteria dapat dihitung sebagai berikut :

$$
\begin{array}{ll}
\text { Nilai prioritas kriteria Masa Kerja } & : \frac{1.48}{5}=0.29 \\
\text { Nilai prioritas kriteria Pendidikan } & : \frac{1.2}{5}=0.24 \\
\text { Nilai prioritas kriteria Kedisiplinan } & : \frac{0.94}{5}=0.18 \\
\text { Nilai prioritas kriteria Loyalitas } & : \frac{0.62}{5}=0.12
\end{array}
$$


Nilai prioritas kriteria Prestasi Kerja

$$
: \frac{0.66}{5}=0.13
$$

b. $\lambda$ maks $=(1.48 / 0.29)+(1.2 / 0.24)+(0.94 / 0.18)+(0.62 / 0.12)+(0.66 / 0.13) / 5$

$$
\begin{array}{ll} 
& =25.53 / 5=5.10 \\
\mathrm{CI} & =(\lambda \text { maks-n }) / \mathrm{n}-1 \\
& =(5.10-5) / 5-1=0.025 \\
\mathrm{CR} & =\mathrm{CI} / \mathrm{RI} \\
& =0.025 / 1.12=0.02
\end{array}
$$

Berikut ini merupakan proses pencarian bobot kriteria dalam memilih Hakim terbaik dengan menerapkan metode Analytical Hierarchy Process (AHP).

Tabel 4. Keterangan Kriteria

\begin{tabular}{ccc}
\hline Kriteria & Keterangan & Bobot \\
\hline C1 & Masa Kerja & 0.29 \\
C2 & Pendidikan & 0.24 \\
C3 & Kedisiplinan & 0.18 \\
C4 & Loyalitas & 0.12 \\
C5 & Prestasi & 0.13 \\
\hline
\end{tabular}

Bobot pada setiap kriteria didefinisikan sebagai $\mathrm{Wj}$ yaitu $=0.29 ; 0.24 ; 0.18 ; 0.12 ; 0.13$

1. Perangkingan

Setelah nilai bobot sudah didapat menggunakan metode Analytical Hierarchy Process (AHP), selanjutnya menggunakan metode Promethee II untuk mencari perankingan pemilihan Hakim terbaik.

2. Data Alternatif

Alternatif merupakan hal yang harus ada di sebuah Sistem Pendukung Keputusan (SPK). Berikut merupakan 15 nama Hakim yang akan dipilih menjadi Hakim terbaik.

Tabel. 5 Data Alternatif

\begin{tabular}{|c|c|c|c|c|c|}
\hline \multirow{2}{*}{ Alternatif } & \multicolumn{5}{|c|}{ Kriteria } \\
\hline & MK & $\mathrm{P}$ & K & $\mathrm{L}$ & $\mathrm{P}$ \\
\hline Drs. Bakhtiar, SH & 5 Tahun & $\mathrm{S} 1$ & Disiplin & Sangat Bagus & $2-3$ \\
\hline Auzar Nawawi, S.Ag., SH & 3 Tahun & $\mathrm{S} 1$ & Cukup Disiplin & Bagus & $0-1$ \\
\hline Drs. H. Rusli, SH., MH & 3 Tahun & $\mathrm{S} 2$ & Disiplin & Sangat Bagus & $0-1$ \\
\hline $\begin{array}{c}\text { Drs. H. Dahlan Siregar, SH., } \\
\text { MH }\end{array}$ & 3 Tahun & $\mathrm{S} 2$ & Disiplin & Cukup Bagus & $2-3$ \\
\hline $\begin{array}{l}\text { Drs. H.Burhanuddin } \\
\text { Harahap, SH }\end{array}$ & 3 Tahun & $\mathrm{S} 1$ & Cukup Disiplin & Sangat Bagus & $0-1$ \\
\hline Drs. H. Zuharnel Maas, SH & 3 Tahun & $\mathrm{S} 1$ & Cukup Disiplin & Sangat Bagus & $\begin{array}{l}0-1 \\
\text { Page | } 458\end{array}$ \\
\hline
\end{tabular}

\begin{tabular}{ccl}
\hline & \multicolumn{1}{c}{ NIP } & \\
1 & 195602021990031002 & \multicolumn{1}{c}{ NAMA } \\
2 & 195702251983021003 & Drs. Bakhtiar, SH \\
3 & 195812301992031002 & Drs. H. Rusli, SH., MH \\
4 & 195412301983031003 & Drs. H. Dahlan Siregar, SH., MH \\
5 & 195605151981031007 & Drs. H.Burhanuddin Harahap, SH \\
6 & 195705011983021001 & Drs. H. Zuharnel Maas, SH \\
7 & 195411081981021001 & Drs. Syamsul Bahri, SH \\
8 & 196602101994032005 & Dra. Hj. Misnah, SH \\
9 & 196212231994031002 & Drs. M. Jhon Afrijal, SH., MH \\
10 & 196206081993031002 & Drs. H. Hudri, SH., MH \\
11 & 196406061994031006 & Drs. H. Mhd. Dongan \\
12 & 196002121993031001 & Drs. Lisman, SH., MH \\
13 & 196811111993031005 & Drs. Ahmad Riva'i, SH \\
14 & 196207231991032003 & Drs. Hj. Emmafatri, SH., MH \\
15 & 196711171994031003 & Drs. Muhammad Kasim, M.H \\
\hline
\end{tabular}

3. Nilai Alternatif

Nilai alternatif merupakan nilai yang sudah ditentukan untuk setiap alternatif yang sebelumnya ditampilkan tabel nilai alternatif untuk setiap kriteria, tampilan tabel sebagai berikut:

Tabel 6. Nilai Alternatif Untuk Setiap Kriteria 
Drs. Syamsul Bahri, SH

Dra. Hj. Misnah, SH

Drs. M. Jhon Afrijal, SH., $\mathrm{MH}$

Drs. H. Hudri, SH., MH

Drs. H. Mhd. Dongan, SH

Drs. Lisman, SH., MH

Drs. Ahmad Riva'i, SH

Drs. Hj. Emmafatri, SH., $\mathrm{MH}$

Drs. Muhammad Kasim, M.H

$\begin{array}{lr}3 \text { Tahun } & \text { S1 } \\ \text { 3 Tahun } & \text { S1 } \\ \text { 2 Tahun } & \text { S2 } \\ & \\ \text { 3 Tahun } & \text { S2 } \\ \text { 2 Tahun } & \text { S1 } \\ \text { 2 Tahun } & \text { S2 } \\ \text { 2 Tahun } & \text { S1 } \\ \text { 2 Tahun } & \text { S2 } \\ & \end{array}$

2 Tahun $\quad$ S2

S1

S1

S2

$\mathrm{S} 2$

$\mathrm{S} 1$

Cukup Disiplin

Cukup Disiplin

Cukup Disiplin

Cukup Disiplin

Sangat Disiplin
Disiplin

Disiplin
Sangat Disiplin
Disiplin
Disiplin
Cukup Disiplin
Cukup Disiplin
Cukup Disiplin
Cukup Disiplin
Sangat Disiplin

Tabel 7 Rating kecocokan Alternatif dan Kriteria

\begin{tabular}{llllll}
\hline & $\mathrm{C}_{1}$ & $\mathrm{C}_{2}$ & $\mathrm{C}_{3}$ & $\mathrm{C}_{4}$ & $\mathrm{C}_{5}$ \\
\hline $\mathrm{A} 1$ & 5 Tahun & 80 & 80 & 100 & 80 \\
$\mathrm{~A} 2$ & 3 Tahun & 80 & 60 & 80 & 60 \\
$\mathrm{~A} 3$ & 3 Tahun & 100 & 100 & 100 & 60 \\
$\mathrm{~A} 4$ & 3 Tahun & 100 & 100 & 60 & 80 \\
$\mathrm{~A} 5$ & 3 Tahun & 80 & 60 & 100 & 60 \\
$\mathrm{~A} 6$ & 3 Tahun & 80 & 60 & 100 & 60 \\
$\mathrm{~A} 7$ & 3 Tahun & 80 & 80 & 80 & 60 \\
$\mathrm{~A} 8$ & 3 Tahun & 80 & 100 & 100 & 60 \\
$\mathrm{~A} 9$ & 2 Tahun & 100 & 80 & 60 & 60 \\
$\mathrm{~A} 10$ & 3 Tahun & 100 & 80 & 100 & 80 \\
$\mathrm{~A} 11$ & 2 Tahun & 80 & 60 & 100 & 60 \\
$\mathrm{~A} 12$ & 2 Tahun & 100 & 60 & 80 & 60 \\
$\mathrm{~A} 13$ & 2 Tahun & 80 & 60 & 60 & 60 \\
$\mathrm{~A} 14$ & 2 Tahun & 100 & 60 & 60 & 60 \\
$\mathrm{~A} 15$ & 2 Tahun & 100 & 100 & 80 & 60 \\
\hline
\end{tabular}

Dari data yang diperoleh dari Rating kecocokan Alternatif dan Kriteria, maka dibuat sebuah matriks Awal

$$
\mathrm{C}=\left[\begin{array}{ccccc}
5 & 80 & 80 & 100 & 80 \\
3 & 80 & 60 & 80 & 60 \\
3 & 100 & 80 & 100 & 60 \\
3 & 80 & 80 & 60 & 80 \\
3 & 80 & 60 & 100 & 60 \\
3 & 80 & 60 & 100 & 60 \\
3 & 80 & 80 & 80 & 60 \\
3 & 80 & 100 & 100 & 60 \\
2 & 100 & 80 & 60 & 60 \\
3 & 100 & 80 & 100 & 80 \\
2 & 80 & 60 & 100 & 60 \\
2 & 100 & 60 & 80 & 60 \\
2 & 80 & 60 & 60 & 60 \\
2 & 100 & 60 & 60 & 60 \\
2 & 100 & 100 & 80 & 60
\end{array}\right]
$$

1. Menormalisasi matriks keputusan dengan menggunakan persamaan 1, sebagai berikut:

Dimana Max $(\mathrm{Xij})=\mathrm{C} 1=5, \mathrm{C} 2=100, \mathrm{C} 3=100, \mathrm{C} 4=100, \mathrm{C} 5=80$

$\operatorname{Min}(\mathrm{Xij})=\mathrm{C} 1=2, \mathrm{C} 2=80, \mathrm{C} 3=60, \mathrm{C} 4=60, \mathrm{C} 5=60$

Matriks keputusan yang ternormalisasi dibuat dari hasil normalisasi diatas

$\begin{array}{cc}\text { Bagus } & 0-1 \\ \text { Sangat Bagus } & 0-1 \\ \text { Cukup Bagus } & 0-1 \\ & \\ \text { Sangat Bagus } & 2-3 \\ \text { Sangat Bagus } & 0-1 \\ \text { Bagus } & 0-1 \\ \text { Cukup Bagus } & 0-1 \\ \text { Cukup Bagus } & 0-1 \\ \text { Bagus } & 0-1\end{array}$

$0-1$

$0-1$

2-3

$0-1$

0-1

0-1

0-1 


$$
\left[\begin{array}{ccccc}
1 & 0 & 0.5 & 1 & 1 \\
0.33 & 0 & 0 & 0.5 & 0 \\
0.33 & 1 & 0.5 & 1 & 0 \\
0.33 & 0 & 0.5 & 0 & 1 \\
0.33 & 0 & 0 & 1 & 0 \\
0.33 & 0 & 0 & 1 & 0 \\
0.33 & 0 & 0.5 & 0.5 & 0 \\
0.33 & 0 & 1 & 1 & 0 \\
0.33 & 1 & 0.5 & 0 & 0 \\
0 & 1 & 0.5 & 1 & 1 \\
0.33 & 0 & 0 & 1 & 0 \\
0 & 1 & 0 & 0.5 & 0 \\
0 & 0 & 0 & 0 & 0 \\
0 & 1 & 0 & 0 & 0 \\
0 & 1 & 1 & 0.5 & 0
\end{array}\right]
$$

2. Menghitung preferensi, menggunakan persamaan 2

Tabel 9 Nilai Preferensi Agrerat

\begin{tabular}{|c|c|c|c|c|c|c|c|c|c|c|c|}
\hline Alternatif & MK & $\mathbf{P}$ & $\mathbf{K}$ & $\mathbf{L}$ & Pr & Alternatif & MK & $\mathbf{P}$ & $\mathbf{K}$ & $\mathbf{L}$ & Pr \\
\hline $\operatorname{Pj}(1,2)$ & 0.67 & 0 & 0.5 & 0.5 & 1 & $\mathrm{Pj}(4,8)$ & 0 & 0 & 0 & 0 & 1 \\
\hline $\mathrm{Pj}(1,3)$ & 0.67 & 0 & 0 & 0 & 1 & $\operatorname{Pj}(4,9)$ & 0 & 0 & 0 & 0 & 1 \\
\hline $\operatorname{Pj}(1,4)$ & 0.67 & 0 & 0 & 1 & 0 & $\operatorname{Pj}(4,10)$ & 0.33 & 0 & 0 & 0 & 0 \\
\hline $\operatorname{Pj}(1,5)$ & 0.67 & 0 & 0.5 & 0 & 1 & $\mathrm{Pj}(4,11)$ & 0 & 0 & 0.5 & 0 & 1 \\
\hline $\operatorname{Pj}(1,6)$ & 0.67 & 0 & 0.5 & 0 & 1 & $\mathrm{Pj}(4,12)$ & 0.33 & 0 & 0.5 & 0 & 1 \\
\hline $\mathrm{Pj}(1,7)$ & 0.67 & 0 & 0 & 0.5 & 1 & $\mathrm{Pj}(4,13)$ & 0.33 & 0 & 0.5 & 0 & 1 \\
\hline $\mathrm{Pj}(1,8)$ & 0.67 & 0 & 0 & 0 & 1 & $\operatorname{Pj}(4,14)$ & 0.33 & 0 & 0.5 & 0 & 1 \\
\hline $\operatorname{Pj}(1,9)$ & 0.67 & 0 & 0 & 1 & 1 & $\operatorname{Pj}(4,15)$ & 0.33 & 0 & 0 & 0 & 1 \\
\hline $\mathrm{Pj}(1,10)$ & 1 & 0 & 0 & 0 & 0 & $\operatorname{Pj}(5,1)$ & 0 & 0 & 0 & 0 & 0 \\
\hline $\mathrm{Pj}(1,11)$ & 0.67 & 0 & 0.5 & 0 & 1 & $\mathrm{Pj}(5,2)$ & 0 & 0 & 0 & 0.5 & 0 \\
\hline $\mathrm{Pj}(1,12)$ & 1 & 0 & 0.5 & 0.5 & 1 & $\operatorname{Pj}(5,3)$ & 0 & 0 & 0 & 0 & 0 \\
\hline $\operatorname{Pj}(1,13)$ & 1 & 0 & 0.5 & 1 & 1 & $\operatorname{Pj}(5,4)$ & 0 & 0 & 0 & 1 & 0 \\
\hline $\mathrm{Pj}(1,14)$ & 1 & 0 & 0.5 & 1 & 1 & $\operatorname{Pj}(5,6)$ & 0 & 0 & 0 & 0 & 0 \\
\hline $\mathrm{Pj}(1,15)$ & 1 & 0 & 0 & 0.5 & 1 & $\operatorname{Pj}(5,7)$ & 0 & 0 & 0 & 0.5 & 0 \\
\hline $\operatorname{Pj}(2,1)$ & 0 & 0 & 0 & 0 & 0 & $\operatorname{Pj}(5,8)$ & 0 & 0 & 0 & 0 & 0 \\
\hline $\operatorname{Pj}(2,3)$ & 0 & 0 & 0 & 0 & 0 & $\operatorname{Pj}(5,9)$ & 0 & 0 & 0 & 1 & 0 \\
\hline $\mathrm{Pj}(2,4)$ & 0 & 0 & 0 & 0.5 & 0 & $\operatorname{Pj}(5,10)$ & 0.33 & 0 & 0 & 0 & 0 \\
\hline $\mathrm{Pj}(2,5)$ & 0 & 0 & 0 & 0 & 0 & $\operatorname{Pj}(5,11)$ & 0 & 0 & 0 & 0 & 0 \\
\hline $\mathrm{Pj}(2,6)$ & 0 & 0 & 0 & 0 & 0 & $\operatorname{Pj}(5,12)$ & 0.33 & 0 & 0 & 0.5 & 0 \\
\hline $\operatorname{Pj}(2,7)$ & 0 & 0 & 0 & 0 & 0 & $\operatorname{Pj}(5,13)$ & 0.33 & 0 & 0 & 1 & 0 \\
\hline $\mathrm{Pj}(2,8)$ & 0 & 0 & 0 & 0 & 0 & $\operatorname{Pj}(5,14)$ & 0.33 & 0 & 0 & 1 & 0 \\
\hline $\mathrm{Pj}(2,9)$ & 0 & 0 & 0 & 0.5 & 0 & $\operatorname{Pj}(5,15)$ & 0.33 & 0 & 0 & 0.5 & 0 \\
\hline $\operatorname{Pj}(2,10)$ & 0.33 & 0 & 0 & 0 & 0 & $\operatorname{Pj}(6,1)$ & 0 & 0 & 0 & 0 & 0 \\
\hline $\mathrm{Pj}(2,11)$ & 0 & 0 & 0 & 0 & 0 & $\operatorname{Pj}(6,2)$ & 0 & 0 & 0 & 0.5 & 0 \\
\hline $\operatorname{Pj}(2,12)$ & 0.33 & 0 & 0 & 0 & 0 & $\operatorname{Pj}(6,3)$ & 0 & 0 & 0 & 0 & 0 \\
\hline $\mathrm{Pj}(2,13)$ & 0.33 & 0 & 0 & 0.5 & 0 & $\operatorname{Pj}(6,4)$ & 0 & 0 & 0 & 1 & 0 \\
\hline $\operatorname{Pj}(2,14)$ & 0.33 & 0 & 0 & 0.5 & 0 & $\mathrm{Pj}(6,5)$ & 0 & 0 & 0 & 0 & 0 \\
\hline $\operatorname{Pj}(2,15)$ & 0.33 & 0 & 0 & 0 & 0 & $\operatorname{Pj}(6,7)$ & 0 & 0 & 0 & 0.5 & 0 \\
\hline $\operatorname{Pj}(3,1)$ & 0 & 1 & 0 & 0 & 0 & $\operatorname{Pj}(6,8)$ & 0 & 0 & 0 & 0 & 0 \\
\hline $\mathrm{Pj}(3,2)$ & 0 & 1 & 0.5 & 0.5 & 0 & $\operatorname{Pj}(6,9)$ & 0 & 0 & 0 & 1 & 0 \\
\hline $\mathrm{Pj}(3,4)$ & 0 & 1 & 0 & 0 & 0 & $\operatorname{Pj}(6,10)$ & 0.33 & 0 & 0 & 0 & 0 \\
\hline $\mathrm{Pj}(3,5)$ & 0 & 1 & 0.5 & 0 & 0 & $\operatorname{Pj}(6,11)$ & 0 & 0 & 0 & 0 & 0 \\
\hline $\operatorname{Pj}(3,6)$ & 0 & 1 & 0.5 & 0.5 & 0 & $\operatorname{Pj}(6,12)$ & 0.33 & 0 & 0 & 0.5 & 0 \\
\hline $\mathrm{Pj}(3,7)$ & 0 & 1 & 0 & 0 & 0 & $\operatorname{Pj}(6,13)$ & 0.33 & 0 & 0 & 1 & 0 \\
\hline $\mathrm{Pj}(3,8)$ & 0 & 1 & 0 & 1 & 0 & $\operatorname{Pj}(6,14)$ & 0.33 & 0 & 0 & 1 & 0 \\
\hline $\mathrm{Pj}(3,9)$ & 0 & 0 & 0 & 0 & 0 & $\operatorname{Pj}(6,15)$ & 0.33 & 0 & 0 & 0.5 & 0 \\
\hline $\operatorname{Pj}(3,10)$ & 0.33 & 0 & 0 & 0 & 0 & $\operatorname{Pj}(7,1)$ & 0 & 0 & 0 & 0 & 0 \\
\hline $\mathrm{Pj}(3,11)$ & 0 & 1 & 0.5 & 0.5 & 0 & $\operatorname{Pj}(7,2)$ & 0 & 0 & 0.5 & 0 & 0 \\
\hline $\operatorname{Pj}(3,12)$ & 0.33 & 0 & 0.5 & 0.5 & 0 & $\operatorname{Pj}(7,3)$ & 0 & 0 & 0 & 0 & 0 \\
\hline $\operatorname{Pj}(3,13)$ & 0.33 & 1 & 0.5 & 1 & 0 & $\operatorname{Pj}(7,4)$ & 0 & 0 & 0 & 0.5 & 0 \\
\hline
\end{tabular}




\begin{tabular}{|c|c|c|c|c|c|c|c|c|c|c|}
\hline $\operatorname{Pj}(3,14)$ & 0.33 & 0 & 0.5 & 1 & 0 & $\mathrm{Pj}(7,5)$ & 0 & 0 & 0.5 & 0 \\
\hline $\operatorname{Pj}(3,15)$ & 0.33 & 0 & 0 & 0.5 & 0 & $\mathrm{Pj}(7,6)$ & 0 & 0 & 0.5 & 0 \\
\hline $\operatorname{Pj}(4,1)$ & 0 & 0 & 0 & 0 & 0 & $\mathrm{Pj}(7,8)$ & 0 & 0 & 0 & 0 \\
\hline $\operatorname{Pj}(4,2)$ & 0 & 0 & 0.5 & 0 & 1 & $\mathrm{Pj}(7,9)$ & 0 & 0 & 0 & 0.5 \\
\hline $\mathrm{Pj}(4,3)$ & 0 & 0 & 0 & 0 & 1 & $\operatorname{Pj}(7,10)$ & 0.33 & 0 & 0 & 0 \\
\hline $\mathrm{Pj}(4,5)$ & 0 & 0 & 0.5 & 0 & 1 & $\operatorname{Pj}(7,11)$ & 0 & 0 & 0.5 & 0 \\
\hline $\mathrm{Pj}(4,6)$ & 0 & 0 & 0.5 & 0 & 1 & $\operatorname{Pj}(7,12)$ & 0.33 & 0 & 0.5 & 0 \\
\hline $\operatorname{Pj}(4,7)$ & 0 & 0 & 0 & 0 & 1 & $\operatorname{Pj}(7,13)$ & 0.33 & 0 & 0.5 & 0.5 \\
\hline $\operatorname{Pj}(7,14)$ & 0.33 & 0 & 0.5 & 0.5 & 0 & $\operatorname{Pj}(11,13)$ & 0.33 & 0 & 0 & 1 \\
\hline $\operatorname{Pj}(7,15)$ & 0.33 & 0 & 0 & 0 & 0 & $\operatorname{Pj}(11,14)$ & 0.33 & 0 & 0 & 1 \\
\hline $\operatorname{Pj}(8,1)$ & 0 & 0 & 0.5 & $0-$ & 0 & $\operatorname{Pj}(11,15)$ & 0.33 & 0 & 0 & 0.5 \\
\hline $\mathrm{Pj}(8,2)$ & 0 & 0 & 1 & 0.5 & 0 & $\operatorname{Pj}(12,1)$ & 0 & 1 & 0 & 0 \\
\hline $\mathrm{Pj}(8,3)$ & 0 & 0 & 0.5 & 0 & 0 & $\operatorname{Pj}(12,2)$ & 0 & 1 & 0 & 0 \\
\hline $\mathrm{Pj}(8,4)$ & 0 & 0 & 0.5 & 1 & 0 & $\operatorname{Pj}(12,3)$ & 0 & 0 & 0 & 0 \\
\hline $\operatorname{Pj}(8,5)$ & 0 & 0 & 1 & 0 & 0 & $\operatorname{Pj}(12,4)$ & 0 & 1 & 0 & 0.5 \\
\hline $\operatorname{Pj}(8,6)$ & 0 & 0 & 1 & 0.5 & 0 & $\operatorname{Pj}(12,5)$ & 0 & 1 & 0 & 0 \\
\hline $\mathrm{Pj}(8,7)$ & 0 & 0 & 0.5 & 0.5 & 0 & $\operatorname{Pj}(12,6)$ & 0 & 1 & 0 & 0 \\
\hline $\operatorname{Pj}(8,9)$ & 0 & 0 & 0.5 & 1 & 0 & $\mathrm{Pj}(12,7)$ & 0 & 1 & 0 & 0 \\
\hline $\mathrm{Pj}(8,10)$ & 0.33 & 0 & 0.5 & 0 & 0 & $\operatorname{Pj}(12,8)$ & 0 & 1 & 0 & 0 \\
\hline $\operatorname{Pj}(8,11)$ & 0 & 0 & 1 & 0 & 0 & $\operatorname{Pj}(12,9)$ & 0 & 0 & 0 & 0.5 \\
\hline $\mathrm{Pj}(8,12)$ & 0.33 & 0 & 1 & 0.5 & 0 & $\operatorname{Pj}(12.10)$ & 0 & 0 & 0 & 0 \\
\hline $\mathrm{Pj}(8,13)$ & 0.33 & 0 & 1 & 0 & 0 & $\operatorname{Pj}(12,11)$ & 0 & 1 & 0 & 0 \\
\hline $\operatorname{Pj}(8,14)$ & 0.33 & 0 & 1 & 0 & 0 & $\operatorname{Pj}(12,13)$ & 0 & 1 & 0 & 0.5 \\
\hline $\operatorname{Pj}(8,15)$ & 0.33 & 0 & 0 & 0.5 & 0 & $\operatorname{Pj}(12,14)$ & 0 & 0 & 0 & 0.5 \\
\hline $\operatorname{Pj}(9,1)$ & 0 & 1 & 0 & 0 & 0 & $\operatorname{Pj}(12,15)$ & 0 & 0 & 0 & 0 \\
\hline $\operatorname{Pj}(9,2)$ & 0 & 1 & 0.5 & 0 & 0 & $\operatorname{Pj}(13,1)$ & 0 & 0 & 0 & 0 \\
\hline $\operatorname{Pj}(9,3)$ & 0 & 0 & 0 & 0 & 0 & $\operatorname{Pj}(13,2)$ & 0 & 0 & 0 & 0 \\
\hline $\operatorname{Pj}(9,4)$ & 0 & 1 & 0 & 0 & 0 & $\operatorname{Pj}(13,3)$ & 0 & 0 & 0 & 0 \\
\hline $\mathrm{Pj}(9,5)$ & 0 & 1 & 0.5 & 0 & 0 & $\operatorname{Pj}(13,4)$ & 0 & 0 & 0 & 0 \\
\hline $\operatorname{Pj}(9,6)$ & 0 & 1 & 0.5 & 0 & 0 & $\operatorname{Pj}(13,5)$ & 0 & 0 & 0 & 0 \\
\hline$P j(9,7)$ & 0 & 1 & 0 & 0 & 0 & $\operatorname{Pj}(13,6)$ & 0 & 0 & 0 & 0 \\
\hline $\operatorname{Pj}(9,8)$ & 0 & 1 & 0 & 0 & 0 & $\operatorname{Pj}(13,7)$ & 0 & 0 & 0 & 0 \\
\hline $\mathrm{Pj}(9,10)$ & 0.33 & 0 & 0 & 0 & 0 & $\mathrm{Pj}(13,8)$ & 0 & 0 & 0 & 0 \\
\hline $\operatorname{Pj}(9,11)$ & 0 & 1 & 0.5 & 0 & 0 & $\operatorname{Pj}(13,9)$ & 0 & 0 & 0 & 0 \\
\hline $\mathrm{Pj}(9,12)$ & 0.33 & 0 & 0.5 & 0 & 0 & $\operatorname{Pj}(13,10)$ & 0 & 0 & 0 & 0 \\
\hline $\operatorname{Pj}(9,13)$ & 0.33 & 1 & 0.5 & 0 & 0 & $\operatorname{Pj}(13,11)$ & 0 & 0 & 0 & 0 \\
\hline $\mathrm{Pj}(9,14)$ & 0.33 & 0 & 0.5 & 0 & 0 & $\operatorname{Pj}(13,12)$ & 0 & 0 & 0 & 0 \\
\hline $\operatorname{Pj}(9,15)$ & 0.33 & 0 & 0 & 0 & 0 & $\operatorname{Pj}(13,14)$ & 0 & 0 & 0 & 0 \\
\hline $\operatorname{Pj}(10,1)$ & 0 & 1 & 0 & 0 & 0 & $\operatorname{Pj}(13,15)$ & 0 & 0 & 0 & 0 \\
\hline $\mathrm{Pj}(10,2)$ & 0 & 1 & 0.5 & 0.5 & 1 & $\operatorname{Pj}(14,1)$ & 0 & 1 & 0 & 0 \\
\hline $\operatorname{Pj}(10,3)$ & 0 & 0 & 0 & 0 & 1 & $\operatorname{Pj}(14,2)$ & 0 & 1 & 0 & 0 \\
\hline $\mathrm{Pj}(10,4)$ & 0 & 1 & 0 & 1 & 0 & $\operatorname{Pj}(14,3)$ & 0 & 0 & 0 & 0 \\
\hline $\mathrm{Pj}(10,5)$ & 0 & 1 & 0.5 & 0 & 1 & $\operatorname{Pj}(14,4)$ & 0 & 1 & 0 & 0 \\
\hline $\mathrm{Pj}(10,6)$ & 0 & 1 & 0.5 & 0.5 & 1 & $\operatorname{Pj}(14,5)$ & 0 & 1 & 0 & 0 \\
\hline $\mathrm{Pj}(10,7)$ & 0 & 1 & 0 & 0.5 & 1 & $\operatorname{Pj}(14,6)$ & 0 & 1 & 0 & 0 \\
\hline $\mathrm{Pj}(10,8)$ & 0 & 1 & 0 & 0 & 1 & $\operatorname{Pj}(14,7)$ & 0 & 1 & 0 & 0 \\
\hline $\operatorname{Pj}(10,9)$ & 0 & 0 & 0 & 1 & 1 & $\mathrm{Pj}(14,8)$ & 0 & 1 & 0 & 0 \\
\hline $\operatorname{Pj}(10,11)$ & 0 & 1 & 0.5 & 0 & 1 & $\operatorname{Pj}(14,9)$ & 0 & 0 & 0 & 0 \\
\hline $\operatorname{Pj}(10,12)$ & 0 & 0 & 0.5 & 0.5 & 1 & $\operatorname{Pj}(14,10)$ & 0 & 0 & 0 & 0 \\
\hline $\operatorname{Pj}(10,13)$ & 0 & 1 & 0.5 & 1 & 1 & $\operatorname{Pj}(14,11)$ & 0 & 1 & 0 & 0 \\
\hline $\operatorname{Pj}(10,14)$ & 0 & 0 & 0.5 & 1 & 1 & $\operatorname{Pj}(14,12)$ & 0 & 1 & 0 & 0 \\
\hline $\operatorname{Pj}(10,15)$ & 0 & 0 & 0 & 0.5 & 1 & $\operatorname{Pj}(14,13)$ & 0 & 0 & 0 & 0 \\
\hline $\operatorname{Pj}(11,1)$ & 0 & 0 & 0 & 0 & 0 & $\operatorname{Pj}(14,15)$ & 0 & 0 & 0 & 0 \\
\hline $\mathrm{Pj}(11,2)$ & 0 & 0 & 0 & 0.5 & 0 & $\operatorname{Pj}(15,1)$ & 0 & 1 & 0.5 & 0 \\
\hline $\mathrm{Pj}(11,3)$ & 0 & 0 & 0 & 0 & 0 & $\operatorname{Pj}(15,2)$ & 0 & 1 & 1 & 0 \\
\hline $\mathrm{Pj}(11,4)$ & 0 & 0 & 0 & 1 & 0 & $\operatorname{Pj}(15,3)$ & 0 & 0 & 0.5 & 0 \\
\hline $\operatorname{Pj}(11,5)$ & 0 & 0 & 0 & 0 & 0 & $\operatorname{Pj}(15,4)$ & 0 & 1 & 0.5 & 0.5 \\
\hline $\mathrm{Pj}(11,6)$ & 0 & 0 & 0 & 0.5 & 0 & $\operatorname{Pj}(15,5)$ & 0 & 1 & 1 & 0 \\
\hline $\operatorname{Pj}(11,7)$ & 0 & 0 & 0 & 0.5 & 0 & $\mathrm{Pj}(15,6)$ & 0 & 1 & 1 & 0 \\
\hline
\end{tabular}




\begin{tabular}{llllllllllll}
$\operatorname{Pj}(11,8)$ & 0 & 0 & 0 & 0 & 0 & $\operatorname{Pj}(15,7)$ & 0 & 1 & 0.5 & 0 & 0 \\
$\operatorname{Pj}(11,9)$ & 0 & 0 & 0 & 1 & 0 & $\operatorname{Pj}(15,8)$ & 0 & 1 & 0 & 0 & 0 \\
$\operatorname{Pj}(11,10)$ & 0.33 & 0 & 0 & 0 & 0 & $P j(15,9)$ & 0 & 0 & 0.5 & 0.5 & 0 \\
$\operatorname{Pj} 11,12)$ & 0.33 & 0 & 0 & 0.5 & 0 & $\operatorname{Pj}(15,10)$ & 0 & 0 & 0.5 & 0 & 0 \\
$\operatorname{Pj}(15,11)$ & 0 & 1 & 1 & 0 & 0 & $\operatorname{Pj}(15,13)$ & 0 & 1 & 1 & 0.5 & 0 \\
$\operatorname{Pj}(15,12)$ & 0 & 0 & 1 & 0 & 0 & $\operatorname{Pj}(15,14)$ & 0 & 0 & 1 & 0.5 & 0 \\
\hline
\end{tabular}

3. Perhitungan indeks preferensi menggunakan persamaan ke 3

$(1,2)=\Sigma(0.29 * 0.67)+(0.24 * 0)+(0.18 * 0.5)+(0.12 * 0.5)+(0.13 * 1)=0.4743$

$(1,3)=\Sigma(0.29 * 0.67)+(0.24 * 0)+(0.18 * 0)+(0.12 * 0)+(0.13 * 1)=0.4143$

$(1,4)=\Sigma(0.29 * 0.67)+(0.24 * 0)+(0.18 * 0)+(0.12 * 1)+(0.13 * 0)=0.3143$

$(1,5)=\Sigma(0.29 * 0.67)+(0.24 * 0)+(0.18 * 0.5)+(0.12 * 0)+(0.13 * 1)=0.4143$

$(1,6)=\Sigma(0.29 * 0.67)+(0.24 * 0)+(0.18 * 0.5)+(0.12 * 0)+(0.13 * 1)=0.4143$

$(1,7)=\Sigma(0.29 * 0.67)+(0.24 * 0)+(0.18 * 0)+(0.12 * 0.5)+(0.13 * 1)=0.3843$

$(1,8)=\Sigma(0.29 * 0.67)+(0.24 * 0)+(0.18 * 0)+(0.12 * 0)+(0.13 * 1)=0.3243$

$(1,9)=\Sigma(0.29 * 0.67)+(0.24 * 0)+(0.18 * 0)+(0.12 * 1)+(0.13 * 1)=0.4443$

$(1,10)=\Sigma(0.29 * 1)+(0.24 * 0)+(0.18 * 0)+(0.12 * 0)+(0.13 * 0)=0.29$

$(1,11)=\Sigma(0.29 * 0.67)+(0.24 * 0)+(0.18 * 0.5)+(0.12 * 0)+(0.13 * 1)=0.4143$

$(1,12)=\Sigma(0.29 * 1)+(0.24 * 0)+(0.18 * 0.5)+(0.12 * 0.5)+(0.13 * 1)=0.57$

$(1,13)=\Sigma(0.29 * 1)+(0.24 * 0)+(0.18 * 0.5)+(0.12 * 1)+(0.13 * 1)=0.63$

$(1,14)=\Sigma(0.29 * 1)+(0.24 * 0)+(0.18 * 0.5)+(0.12 * 1)+(0.13 * 1)=0.63$

$(1,15)=\Sigma(0.29 * 1)+(0.24 * 0)+(0.18 * 0)+(0.12 * 0.5)+(0.13 * 1)=0.48$

Tabel 10 Matriks Agregat

\begin{tabular}{|c|c|c|c|c|c|c|c|c|c|c|c|c|c|c|c|c|}
\hline & A1 & A2 & A3 & A4 & A5 & A6 & A7 & A8 & A9 & A10 & A11 & A12 & A13 & A14 & A15 & Total \\
\hline \multirow[t]{2}{*}{ A1 } & - & 0.474 & 0.414 & 0.314 & 0.414 & 0.414 & 0.384 & 0.324 & 0.444 & 0.29 & 0.414 & 0.57 & 0.63 & 0.63 & 0.48 & 6.198 \\
\hline & & 3 & 3 & 3 & 3 & 3 & 3 & 3 & 3 & & 3 & & & & & 7 \\
\hline \multirow[t]{2}{*}{ A2 } & 0 & - & 0 & 0.06 & 0 & 0 & 0 & 0 & 0.06 & 0.095 & 0 & 0.095 & 0.155 & 0.155 & 0.095 & 0.718 \\
\hline & & & & & & & & & & 7 & & 7 & 7 & 7 & 7 & 5 \\
\hline \multirow[t]{2}{*}{$\mathrm{A} 3$} & 0.2 & 0.39 & - & 0.24 & 0.33 & 0.39 & 0.24 & 0.36 & 0 & 0.095 & 0.39 & 0.245 & 0.545 & 0.305 & 0.155 & 3.928 \\
\hline & 4 & & & & & & & & & 7 & & 7 & 7 & 7 & 7 & 5 \\
\hline \multirow[t]{2}{*}{ A4 } & 0 & 0.22 & 0.13 & - & 0.22 & 0.22 & 0.13 & 0.13 & 0.13 & 0.095 & 0.22 & 0.107 & 0.315 & 0.315 & 0.225 & 2.460 \\
\hline & & & & & & & & & & 7 & & 4 & 7 & 7 & 7 & 2 \\
\hline \multirow[t]{2}{*}{ A5 } & 0 & 0.06 & 0 & 0.12 & - & 0 & 0.06 & 0 & 0.12 & 0.095 & 0 & 0.155 & 0.215 & 0.215 & 0.155 & 1.198 \\
\hline & & & & & & & & & & 7 & & 7 & 7 & 7 & 7 & 5 \\
\hline \multirow[t]{2}{*}{ A6 } & 0 & 0.06 & 0 & 0.12 & 0 & - & 0.06 & 0 & 0.12 & 0.095 & 0 & 0.152 & 0.215 & 0.215 & 0.152 & 1.198 \\
\hline & & & & & & & & & & 7 & & 7 & 7 & 7 & 7 & 5 \\
\hline \multirow[t]{2}{*}{ A7 } & 0 & 0.09 & 0 & 0.06 & 0.09 & 0.09 & - & 0 & 0.06 & 0.095 & 0.09 & 0.185 & 0.245 & 0.245 & 0.095 & 1.348 \\
\hline & & & & & & & & & & 7 & & 7 & 7 & 7 & 7 & 5 \\
\hline \multirow[t]{2}{*}{ A8 } & 0.0 & 0.24 & 0.09 & 0.18 & 0.18 & 0.24 & 0.15 & - & 0.21 & 0.185 & 0.18 & 0.335 & 0.275 & 0.275 & 0.155 & 2.788 \\
\hline & 9 & & & & & & & & & 7 & & 7 & 7 & 7 & 7 & 5 \\
\hline \multirow[t]{2}{*}{ A9 } & 0.2 & 0.33 & 0 & 0.24 & 0.33 & 0.33 & 0.24 & 0.24 & - & 0.095 & 0.33 & 0.185 & 0.425 & 0.185 & 0.095 & 3.268 \\
\hline & 4 & & & & & & & & & 7 & & 7 & 7 & 7 & 7 & 5 \\
\hline \multirow[t]{2}{*}{ A10 } & 0.2 & 0.52 & 0.13 & 0.36 & 0.46 & 0.52 & 0.43 & 0.37 & 0.345 & - & 0.46 & 0.28 & 0.58 & 0.34 & 0.19 & 5.225 \\
\hline & 4 & & & & & & & & 7 & & & & & & & 7 \\
\hline \multirow[t]{2}{*}{ A11 } & 0 & 0.06 & 0 & 0.12 & 0 & 0.06 & 0.06 & 0 & 0.12 & 0.095 & - & 0.155 & 0.215 & 0.215 & 0.155 & 1.258 \\
\hline & & & & & & & & & & 7 & & 7 & 7 & 7 & 7 & 5 \\
\hline A 12 & $\begin{array}{l}0.2 \\
4\end{array}$ & 0.24 & 0 & 0.3 & 0.24 & 0.24 & 0.24 & 0.24 & 0.06 & 0 & 0.24 & - & 0.3 & 0.06 & 0 & 2.4 \\
\hline A13 & 0 & 0 & 0 & 0 & 0 & 0 & 0 & 0 & 0 & 0 & 0 & 0 & - & 0 & 0 & 0 \\
\hline A14 & $\begin{array}{l}0.2 \\
4\end{array}$ & 0.24 & 0 & 0.24 & 0.24 & 0.24 & 0.24 & 0.24 & 0 & 0 & 0.24 & 0.24 & 0 & - & 0 & 2.16 \\
\hline A 15 & $\begin{array}{l}0.3 \\
3\end{array}$ & 0.42 & 0.09 & 0.39 & 0.42 & 0.42 & 0.33 & 0.24 & 0.15 & 0.09 & 0.42 & 0.18 & 0.24 & 0.24 & - & 3.96 \\
\hline Tota & 1.6 & 3.344 & 0.854 & 2.744 & 2.924 & 3.164 & 2.564 & 2.144 & 1.82 & 1.331 & 2.984 & 2.887 & 4.361 & 3.401 & 1.961 & \\
\hline 1 & 2 & 3 & 3 & 3 & 3 & 3 & 3 & 3 & & 3 & 3 & & 3 & 3 & 3 & \\
\hline
\end{tabular}

Langkah 4 : Menentukan arus keluar dan arus outrangking

\begin{aligned} \hline \multicolumn{1}{c}{ Leaving flow } & \multicolumn{1}{c}{ Entering flow } \\ \hline$\varphi^{+} \mathrm{P} 1: \frac{1}{15-1} * 6.1987=0.4427 & \varphi^{-} \mathrm{P} 1: \frac{1}{15-1} * 1.62=0.1157 \\ \varphi^{+} \mathrm{P} 2: \frac{1}{15-1} * 0.7185=0.0513 & \varphi^{-} \mathrm{P} 2: \frac{1}{15-1} * 3.3443=0.2388 \\ \varphi^{+} \mathrm{P} 3: \frac{1}{15-1} * 3.9285=0.2806 & \varphi^{-} \mathrm{P} 3: \frac{1}{15-1} * 0.8543=0.0610 \\ \varphi^{+} \mathrm{P} 4: \frac{1}{15-1} * 2.4602=0.1757 & \varphi^{-} \mathrm{P} 4: \frac{1}{15-1} * 2.7443=0.1960 \\ \varphi^{+} \mathrm{P} 5: \frac{1}{15-1} * 1.1985=0.0856 & \varphi^{-} \mathrm{P} 5: \frac{1}{15-1} * 2.9243=0.2088 \\ \varphi^{+} \mathrm{P} 6: \frac{1}{15-1} * 1.1985=0.0856 & \varphi^{-} \mathrm{P} 6: \frac{1}{15-1} * 3.1643=0.2260 \\ \varphi^{+} \mathrm{P} 7: \frac{1}{15-1} * 1.3485=0.0963 & \varphi^{-} \mathrm{P} 7: \frac{1}{15-1} * 2.5643=0.1831\end{aligned}$




$$
\begin{array}{ll}
\varphi^{+} \mathrm{P} 8: \frac{1}{15-1} * 2.7885=0.1991 & \varphi^{-} \mathrm{P} 8: \frac{1}{15-1} * 2.1443=0.1703 \\
\varphi^{+} \mathrm{P} 9: \frac{1}{15-1} * 3.2685=0.2332 & \varphi^{-} \mathrm{P} 9: \frac{1}{15-1} * 1.82=0.1300 \\
\varphi^{+} \mathrm{P} 10: \frac{1}{15-1} * 5.2257=0.3732 & \varphi^{-} \mathrm{P} 10: \frac{1}{15-1} * 1.3313=0.0950 \\
\varphi^{+} \mathrm{P} 11: \frac{1}{15-1} * 1.2585=0.0898 & \varphi^{-} \mathrm{P} 11: \frac{1}{15-1} * 2.9843=0.2131 \\
\varphi^{+} \mathrm{P} 12: \frac{1}{15-1} * 2.4=0.1714 & \varphi^{-} \mathrm{P} 12: \frac{1}{15-1} * 2.887=0.2062 \\
\varphi^{+} \mathrm{P} 13: \frac{1}{15-1} * 0 \quad= & \varphi^{-} \mathrm{P} 13: \frac{1}{15-1} * 4.3613=0.3115 \\
\varphi^{+} \mathrm{P} 14: \frac{1}{15-1} * 2.16=0.1542 & \varphi^{-} \mathrm{P} 14: \frac{1}{15-1} * 3.4013=0.2429 \\
\varphi^{+} \mathrm{P} 15: \frac{1}{15-1} * 3.96=0.2828 & \varphi^{-} \mathrm{P} 15: \frac{1}{15-1} * 1.9613=0.1400 \\
\hline
\end{array}
$$

Tabel 11. Hasil dari leaving flow dan entering flow

\begin{tabular}{lll}
\hline & Leaving flow & Entering flow \\
\hline P1 & 0.4427 & 0.1157 \\
P2 & 0.0513 & 0.2388 \\
P3 & 0.2806 & 0.0610 \\
P4 & 0.1754 & 0.1960 \\
P5 & 0.0856 & 0.2088 \\
P6 & 0.0856 & 0.2260 \\
P7 & 0.0963 & 0.1831 \\
P8 & 0.1991 & 0.1703 \\
P9 & 0.2332 & 0.1300 \\
P10 & 0.3732 & 0.0950 \\
P11 & 0.0898 & 0.2131 \\
P12 & 0.1714 & 0.2062 \\
P13 & 0 & 0.3115 \\
P14 & 0.1542 & 0.2429 \\
P15 & 0.2828 & 0.1400 \\
\hline
\end{tabular}

Langkah 5 Menghitung outranking setiap alternatif

$$
\begin{aligned}
& \text { P1 }=0.4427-0.1157=0.327 \\
& \text { P2 }=0.0513-0.2388=-0.1875 \\
& P 3=0.2806-0.0610=0.2196 \\
& \text { P4 }=0.1754-0.1960=-0.0206 \\
& \text { P5 }=0.0856-0.2588=-0.1732 \\
& P 6=0.0856-0.2260=-0.1404 \\
& \text { P7 }=0.0963-0.1831=-0.0868 \\
& \text { P8 }=0.1948-0.1703=0.0245 \\
& \text { P9 }=0.2332-0.1300=0.1032 \\
& \text { P10 }=0.3732-0.0950=0.2782 \\
& \text { P11 }=0.0898-0.2131=-0.1233 \\
& \text { P12 }=0.1714-0.2062=-0.0348 \\
& \text { P13 }=0-0.3115=-0.3115 \\
& \text { P14 }=0.1542-0.2429=-0.0887 \\
& \text { P15 }=0.2828-0.1400=0.1428
\end{aligned}
$$

Tabel 12. Hasil dari perhitungan outranking

\begin{tabular}{cccccc}
\hline Alternatif & Net flow & Rangking & Alternatif & Net flow & Rangking \\
\hline P1 & 0.327 & 1 & P9 & 0.1032 & 5 \\
P2 & -0.1875 & 8 & P10 & 0.2782 & 2 \\
P3 & 0.2196 & 3 & P11 & -0.1233 & 11 \\
P4 & -0.0206 & 15 & P12 & -0.0348 & 14 \\
P5 & -0.1732 & 9 & P13 & -0.3115 & 7 \\
P6 & -0.1404 & 10 & P14 & -0.0887 & 12 \\
P7 & -0.0868 & 13 & P15 & 0.1428 & 4 \\
P8 & 0.0245 & 6 & & & \\
\hline
\end{tabular}


Berdasarkan perhitungan diatas dapat disimpulkan alternatif yang layak menjadi Hakim terbaik adalahadalah P1 atas nama Drs. Bakhtiar, SH.

\section{KESIMPULAN}

Dari hasil penelitian dan pembahasan maka penulis mengambil kesimpulan sebagai berikut :

1. Proses pemilihan Hakim terbaik dengan menggunakan metode Analytical Hierarchy Process (AHP) dan Promethee II dapat menjadi salah satu pemecahan masalah dalam pemilihan Hakim terbaik di Kantor Pengadilan Agama Medan Kelas 1 A.

2. Dengan menerapkan metode AHP untuk mencari niai pembobotan dan metode Promethee II untuk mencari hasil perankingan.

3. Sistem yang digunakan untuk merancang sistem pendukung keputusan pemilihan Hakim terbaik di Kantor Pengadilan Agama Medan Kelas 1 A dengan menggunakan Visual Studio 2008.

\section{REFERENCES}

[1] S. Yohanna Silalahi, Mesran, Taronisokhi Zebua, "Penerapan The Extended Promethee II (EXPROM II) Untuk Penentuan Produk Diskon," vol. 1, 2017.

[2] S. M Aji Sasongko, Indah Fitri Astuti, "Pemilihan Karyawan Bau Dengan Metode AHP,"2017.

[3] W. K. Muhammad Wafi, Rizal Setya Perdana, "Implementasi Metode Promethee II Untuk Menentukan Pemenang Tender Proyek," 2017.

[4] M. K. Kusrini, Konsep Dan Aplikasi Sistem Pendukung Keputusan. Yogyakarta: Andi, 2007.

[5] M. Annur Rohim Faqih, "Kode Etik Dan Pedoman Perilaku Hakim,” vol. 3, 2013.

[6] Rini Artika, "Penerapan Analitycal Hierarchy Proses (AHP) Dalam Pendukung Keputusan Penilaian Kinerja Guru Pada SD Negeri 095224," vol. 4, 2013.

[7] Adi Nugroho, ANALISIS dan PERANCANGAN SISTEM INFORMASI, Revisi. Bandung: Informatika Bandung, 2005.

[8] Feri Sulianta, Teknik Perancangan Arsitektur Sistem Informasi. Yogyakarta: Andi, 2017.

[9] C. S. D. S. Community, Membangun Aplikasi Database Dengan Visual Basic 2008 dan SQL Server 2008. Jakarta: PT. Alex Media Komputindo, 2010.

[10] Madcoms, Microsoft Access 2007 Untuk Pemula, 1st ed. Madiun: Andi, 2008

[11] Eko Hari Atmoko, Program Akuntansi beserta Manajemen Aset menggunakan VB dan SQL Server. Jakarta: PT. Alex Media Komputindo, 2013. 